\title{
Evaluation of precision of hydrogen isotopic composition determinations by EA-IRMS, GC-IRMS and Py-GC-IRMS
}

\section{Ocena precyzji oznaczeń składu izotopowego wodoru w układach Py-GC-IRMS, GC-IRMS oraz EA-IRMS}

\author{
Marek Janiga, Małgorzata Kania \\ Oil and Gas Institute - National Research Institute
}

\begin{abstract}
The work presents the results of analyzes of the hydrogen isotopic composition of pyrolysis products of a shale sample. The pyrolysis products obtained are: methane, ethene, ethane, propylene, propane, 1-butene and n-butane. The apparatus used is a Thermo Scientific Delta V Advantage mass spectrometer with a Trace GC Ultra chromatograph (HP-PLOT/Q capillary column, $30 \mathrm{~m}$ ) and Pyroprobe 6150 pyrolyzer (pyrolysis temperature $1000^{\circ} \mathrm{C}$, isothermal 30 seconds). The Py-GC-IRMS methodology for determining the hydrogen isotopic composition of pyrolysis gas products was verified by evaluating repeatability. The shale sample was pyrolyzed at $500^{\circ} \mathrm{C}, 600^{\circ} \mathrm{C}, 700^{\circ} \mathrm{C}, 800^{\circ} \mathrm{C}, 900^{\circ} \mathrm{C}$ and $1000^{\circ} \mathrm{C}$. Accordingly, pyrolysis at $500^{\circ} \mathrm{C}$ does not allow the products to be separated. The ratio between unsaturated and saturated hydrocarbons changes, and as the temperature increases, unsaturated ones begin to dominate. The isotopic composition of individual pairs also changes, although the relationship between $\delta \mathrm{D}$ in unsaturated and saturated hydrocarbons is constant. The trend for all components is that at higher pyrolysis temperatures, the isotopic composition is also higher. Herein, the differences in the isotope composition of $900^{\circ} \mathrm{C}$ and $1000^{\circ} \mathrm{C}$ are negligible. The nature of isotopic composition determinations does not allow ascertaining the limit of quantification, the limit of detection and the method bias. Values of relative standard deviations are below five percent only for methane, ethane and propylene. In addition, repeatability tests were performed for EA-IRMS (elemental analyzer combined with isotope mass spectrometer) and GC-IRMS (sample injection directly into the inlet). The samples used were hard coal and natural gas. Repeatability of hydrogen isotopic composition analyzes assessed using relative standard deviation was the best (lowest value) for the GC-IRMS system ( $0.8 \%$ ), then for the Py-GC-IRMS system (methane at $3 \mathrm{mg}-1.2 \%)$ and for EA-IRMS $(2.3 \%)$.
\end{abstract}

Key words: precision, repeatability, EA-IRMS, GC-IRMS, Py-GC-IRMS, $\delta^{2} \mathrm{H}$.

STRESZCZENIE: Praca przedstawia wyniki analiz składu izotopowego wodoru produktów pirolizy próbki łupku. Otrzymywane produkty pirolizy to: metan, eten, etan, propylen, propan, 1-buten i n-butan. Wykorzystana aparatura to spektrometr masowy Delta V Advantage firmy Thermo Scientific wraz z chromatografem Trace GC Ultra (kolumna kapilarna HP-PLOT/Q, $30 \mathrm{~m}$ ) i pirolizerem Pyroprobe 6150 (temperatura pirolizy: $1000^{\circ} \mathrm{C}$, izoterma: 30 sekund). Układ połączony jest on-line za pośrednictwem Conflo IV. Metodyka Py-GC-IRMS oznaczeń składu izotopowego wodoru gazowych produktów pirolizy została sprawdzona poprzez ocenę powtarzalności. Próbka łupku była pirolizowana w temperaturach: $500^{\circ} \mathrm{C}, 600^{\circ} \mathrm{C}, 700^{\circ} \mathrm{C}, 800^{\circ} \mathrm{C}, 900^{\circ} \mathrm{C}$ i $1000^{\circ} \mathrm{C}$. Piroliza w $500^{\circ} \mathrm{C}$ nie pozwala na wydzielenie produktów. Proporcja pomiędzy nienasyconymi i nasyconymi węglowodorami zmienia się i wraz ze wzrostem temperatury zaczynają dominować węglowodory nienasycone. Skład izotopowy poszczególnych par również ulega zmianie, choć stała jest relacja pomiędzy $\delta \mathrm{D}$ nienasyconych i nasyconych węglowodorów. W przypadku wszystkich składników utrzymuje się trend, że przy wyższej temperaturze pirolizy wartości składu izotopowego są również wyższe. Dodatkowo różnice składu izotopowego w temperaturach $900^{\circ} \mathrm{C}$ i $1000^{\circ} \mathrm{C}$ są już znikome. Charakter oznaczeń składu izotopowego nie pozwala na określenie granicy oznaczalności, granicy wykrywalności oraz obciążenia metody. Wartości względnych odchyleń standardowych są poniżej pięciu procent jedynie dla metanu, etanu i propylenu. Dodatkowo wykonano testy powtarzalności dla układów EA-IRMS (analizator elementarny połączony z izotopowym spektrometrem masowym) oraz GC-IRMS (nastrzyk próbki bezpośrednio do dozownika chromatografu połączonego z ConFlo IV i spektrometrem). Wykorzystane próbki to węgiel kamienny oraz gaz ziemny. Powtarzalność oznaczeń składu izotopowego wodoru oceniana przy użyciu względnego odchylenia standardowego była najlepsza (najniższa wartość) w przypadku układu GC-IRMS (0,8\%), następnie układu Py-GC-IRMS (metan przy naważce $3 \mathrm{mg}-1,2 \%)$ i EA-IRMS (2,3\%).

Słowa kluczowe: precyzja, powtarzalność, EA-IRMS, GC-IRMS, Py-GC-IRMS, $\delta^{2} H$.

Corresponding author: M. Janiga, e-mail: marek.janiga@inig.pl

Article contributed to the Editor: 15.01.2020. Approved for publication: 13.08.2020 


\section{Introduction}

The results of the determination of the hydrogen isotope composition are expressed as:

$$
\delta \mathrm{D}=\left[\left(\mathrm{D} / \mathrm{H}_{\text {test }}-\mathrm{D} / \mathrm{H}_{\mathrm{VSMOW}}\right) /\left(\mathrm{D} / \mathrm{H}_{\mathrm{VSMOW}}\right)\right] \times 1000 \% \text { o }
$$

The reference value (Vienna Standard Mean Ocean Water - VSMOW) is the average isotope composition of hydrogen in sea water. The results of the analyzes are the differences between the isotope composition of the sample and the isotope composition of VSMOW expressed in per mille (Hoefs, 2004; Sharp, 2007; Groot, 2009).

Mass spectrometers (Isotope Ratio Mass Spectrometer - IRMS) are used to determine the isotopic composition of elements having stable isotopes (carbon, nitrogen, oxygen, hydrogen and sulfur). The Oil and Gas Geochemistry Laboratory has a Delta V Advantage mass spectrometer from Thermo Scientific. Due to the high sensitivity and the inability to provide an absolute result, each determination consists of a sample test and a reference gas whose isotope composition is ascertained using certified standards. The sample must be in a gaseous form. For this reason, it is burnt in an elemental analyzer (Flash, 2000) or a GC Isolink device connected to a Trace GC Ultra chromatograph. The flows from the analyzer, chromatograph and reference gases are collected in a ConFlo, a device that allows to "manage" gas streams going to the spectrometer. For the determination of the carbon isotope composition, the sample must be in the form of carbon dioxide, for hydrogen - in the form of $\mathrm{H}_{2}$, for oxygen - in the form of $\mathrm{CO}$, and for nitrogen - in the form of $\mathrm{N}_{2}$. These types of gases are reference for the relevant determinations. The chromatograph on the inlet has a Pyroprobe 6150 pyrolizer (CDS Analytical) attached.

\section{Chromatograph work methodology}

Gas samples are separated on a Trace GC Ultra chromatograph, using a 30-meter HP-PLOT/Q capillary column with a diameter of $0.32 \mathrm{~mm}$. The temperature program starts at $35^{\circ} \mathrm{C}$ (held for 4 minutes). Subsequently, the temperature increases to $210^{\circ} \mathrm{C}$ (held for 5 minutes), whereas the inlet temperature is $150^{\circ} \mathrm{C}$. Further separated gas components leaving the column are burned/pyrolyzed to $\mathrm{CO}_{2}, \mathrm{H}_{2}, \mathrm{~N}_{2}, \mathrm{CO}$ and $\mathrm{H}_{2} \mathrm{O}$ in the reactors of the GC IsoLink device (temperature 1000 and $1400^{\circ} \mathrm{C}$ ). To eliminate moisture, the products of combustion, together with the carrier gas flow through a Nafion tube. They then go to Conflo IV (open split) and IRMS (Delta V Advantage).

\section{Methodology of pyrolyzer work}

The Pyroprobe 6150 pyrolizer consists of two main parts (the "probe" in which the sample is placed and the "interface" in which the probe is placed). Additionally, operating parameters of two zones can be set: transfer line and eight port valve chamber (switching carrier gas flows in two lines).

The sample is placed in a glass (quartz) tube, and then in the probe, in which there is a platinum filament. This is a spring-shaped heating element with a sample tube inside. The temperature and duration of heating are the most important operating parameters of the pyrolyzer. The SS-13 method recommended by the manufacturer for geological samples uses a pyrolysis temperature of $1000^{\circ} \mathrm{C}$ for 30 seconds. The temperature increase is $20^{\circ} \mathrm{C}$ per millisecond.

The probe is placed in an interface which temperature (start, end, rise) can also be programmed. In the SS-13 method, the initial temperature is $50^{\circ} \mathrm{C}$, the increase is $100^{\circ} \mathrm{C} / \mathrm{min}$, the final temperature is $400^{\circ} \mathrm{C}$ (kept for three minutes). The temperatures of the transfer line connecting the pyrolyzer with the chromatograph inlet and the valve chamber are set to $350^{\circ} \mathrm{C}$ and $325^{\circ} \mathrm{C}$, respectively (method SS-13). The pyrolyzer working methods used to carry out the work differ only in the temperature of the pyrolysis in the probe $\left(500^{\circ} \mathrm{C}, 600^{\circ} \mathrm{C}, 700^{\circ} \mathrm{C}, 800^{\circ} \mathrm{C}, 900^{\circ} \mathrm{C}\right.$ and $1000^{\circ} \mathrm{C}$ ). The rest of the parameters are not changed (Kania and Janiga, 2015).

\section{IRMS configuration and preparation for work}

A number of tests are performed before starting the analyzes. The first is the "peak center", followed by "autofocus" or automatic tuning of the optical system parameters. Following this, a repeatability test (so-called "on-off test") of the internal standard (reference gas $-\mathrm{H}_{2}$ ) is performed. This is a ten-fold analysis of the reference isotope composition. The standard deviation for this test must be lower than 0.4 , otherwise no determinations are made (checking the vacuum, looking for leaks, performing "peak center" and "autofocus" again).

The next step is the reference gas linearity test. This is an analysis of the isotope composition of seven peaks of reference gas of varying intensity. Based on this test, the " $\mathrm{H}_{3}$ factor" is determined, which is automatically used by the program to correct the results. All these tests are performed automatically in a computer program that supports the spectrometer (Isodat). The program also automatically calculates the values that must be met in the relevant tests. 


\section{Calibration}

The specificity of GC-IRMS determinations does not allow the creation of multi-point calibration curves. One-point calibration is performed using a standard with a similar matrix and a similar isotope composition to that expected in the samples. Therefore, the Alphagas isotope $-\mathrm{H}_{2}$ standard was used to perform the calibration. The certified gas standard was purchased at Air Liquide Polska, and was prepared in the accredited laboratory of Air Liquide Deutschland GmbH in Dusseldorf. Calibration was performed by injecting gas into the chromatograph inlet. There is no standard for use via the pyrolyzer (Faghihi et al., 2012; Renterghem et al., 2012; Vogl, 2013; Cengiz et al., 2014).

Calibration was performed by analyzing the Alphagas isotope $-\mathrm{H}_{2}$ standard six times with a $\delta \mathrm{D}$ value of $-192 \%$ (PDB) and a standard deviation of 4\%o. The isotope composition of the reference gas was calibrated to $-183.5\left(\mathrm{CO}_{2} \mathrm{Lab}\right.$ Tank $=-183.5$ in the Isodat program).

\section{Method optimization}

The sample weight must be selected so that the peak height is within the range of the Faraday collectors. The highly restrictive Good practice guide for IRMS (Carter and Barwick, 2011) gives a working range of 5 to $15 \mathrm{~V}$ for EA-IRMS. From practice in the Oil and Gas Geochemistry Laboratory, fully reliable results are obtained in the range of about 1 to $30 \mathrm{~V}$. After several weighing trials, the respective peak levels are reached at approximately $3 \mathrm{mg}$ for shale sample. The weighting does not have to be precise, because it effects only into the height of the peaks. Too much sample results in a peak that is cut off. In addition, $\delta \mathrm{D}$ assumes then completely unreliable values.

The shale sample was pyrolyzed at $500^{\circ} \mathrm{C}, 600^{\circ} \mathrm{C}, 700^{\circ} \mathrm{C}$, $800^{\circ} \mathrm{C}, 900^{\circ} \mathrm{C}$ and $1000^{\circ} \mathrm{C}$. Chromatograms for individual temperatures are given in Figures 1 to 6 , and the results are shown in Table 1. Accordingly, pyrolysis at $500^{\circ} \mathrm{C}$ does not allow the receiving of products. However, chromatograms for individual temperatures allow to notice differences in proportions between some components: ethene and ethane, propylene and propane, 1-butene and n-butane. The ratio between unsaturated and saturated hydrocarbons changes, and as the temperature increases, unsaturated ones begin to dominate. The isotopic composition of individual pairs also changes, although the relationship between $\delta \mathrm{D}$ in unsaturated and saturated hydrocarbons is constant. For ethene and ethane, as well as for 1-butene and n-butane, unsaturated hydrocarbons have higher or similar $\delta \mathrm{D}$ values, and for propylene and propane - the opposite. The isotope composition diagram (Fig. 7) shows large changes in $\delta \mathrm{D}$ with increasing temperature. The trend for all components is that at higher pyrolysis temperature, the isotopic composition is also higher (the exception is 1-butene, the values of which vary widely). In addition, the differences in the isotope composition of $900^{\circ} \mathrm{C}$ and $1000^{\circ} \mathrm{C}$ are already negligible.

The SS-13 $\left(1000^{\circ} \mathrm{C}\right)$ method suggested by the manufacturer for geological samples was selected for further work (repeatability).

Table 1. Hydrogen isotopic composition of pyrolysis products obtained at different temperatures [\%o]

Tabela 1. Skład izotopowy wodoru w produktach pirolizy w różnych temperaturach [\%o]

\begin{tabular}{|l|c|c|c|c|c|c|}
\cline { 2 - 7 } & \multicolumn{6}{c|}{ Pyrolysis temperature } \\
\cline { 2 - 7 } & $\mathbf{5 0 0}^{\circ} \mathbf{C}$ & $\mathbf{6 0 0}^{\circ} \mathbf{C}$ & $\mathbf{7 0 0}^{\circ} \mathbf{C}$ & $\mathbf{8 0 0}^{\circ} \mathbf{C}$ & $\mathbf{9 0 0}^{\circ} \mathbf{C}$ & $\mathbf{1 0 0 0}^{\circ} \mathbf{C}$ \\
\hline \hline Methane & - & -251 & -222 & -209 & -207 & -188 \\
\hline Ethene & - & -207 & -176 & -127 & -121 & -126 \\
\hline Ethane & - & -302 & -254 & -219 & -177 & -187 \\
\hline Propylene & - & -217 & -192 & -172 & -182 & -187 \\
\hline Propane & - & -214 & -178 & -143 & -99 & -95 \\
\hline 1-Buthene & - & -98 & -83 & -162 & -107 & -112 \\
\hline n-Buthane & - & -207 & -171 & -155 & -111 & -111 \\
\hline
\end{tabular}

\section{Method validation elements}

Validation is the process of determining the parameters that characterize the performance and limitations of a method, and checking its suitability for specific purposes. As a result of the validation, one can be sure that the analysis process is dependable, precise and gives reliable results.

The method parameters that should be determined during validation or determination of measurement uncertainty are: repeatability of the test method, reproducibility of the test method, measurement accuracy, limit of quantification, detection limit and method load.

In our study, the accuracy of the method (agreement between the actual value and the value resulting from the analysis) could not be checked due to the lack of certified reference materials other than the gas used for calibration. The mixed nature of the isotopic composition (quantitative and qualitative) determinations also does not allow the determination of the limit of quantification (the smallest amount of substance that can be reliably determined), the limit of detection (the smallest amount of substance that can be detected) and the method loading ("difference" between the result of the method obtained tested and the result of testing the same sample using the reference method). In addition, the amount of sample must be selected so that the peaks of the individual compounds fall within the operating range of the detector (Faraday collectors). Thus, a reference method that could be used, hardly exists. 


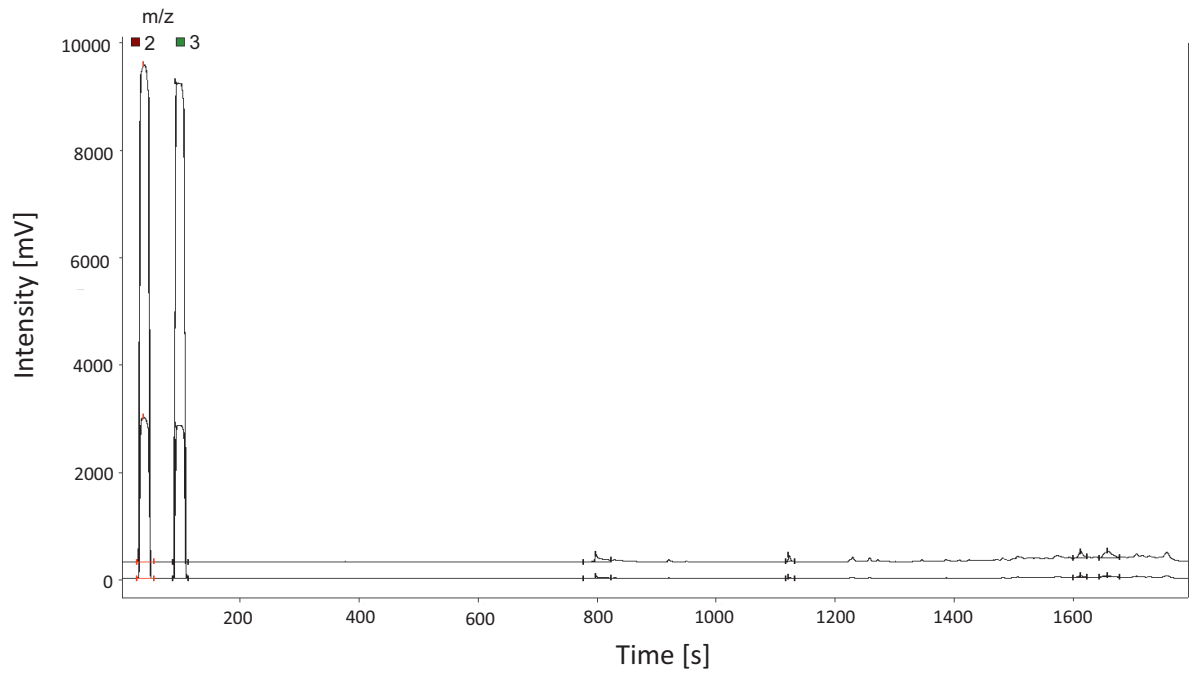

Fig. 1. Chromatogram of shale sample pyrolysed at temperature $500^{\circ} \mathrm{C}$

Rys. 1. Chromatogram próbki łupku - piroliza w temperaturze $500^{\circ} \mathrm{C}$

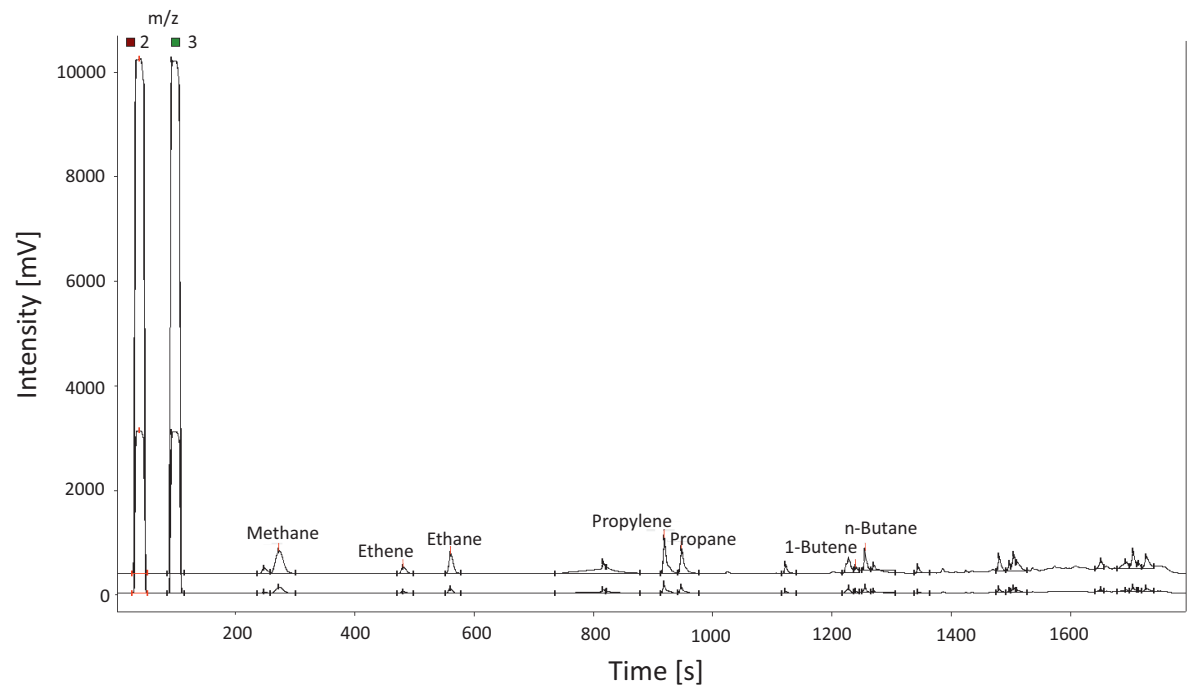

Fig. 2. Chromatogram of shale sample pyrolysed at temperature $600^{\circ} \mathrm{C}$ Rys. 2. Chromatogram próbki łupku - piroliza w temperaturze $600^{\circ} \mathrm{C}$

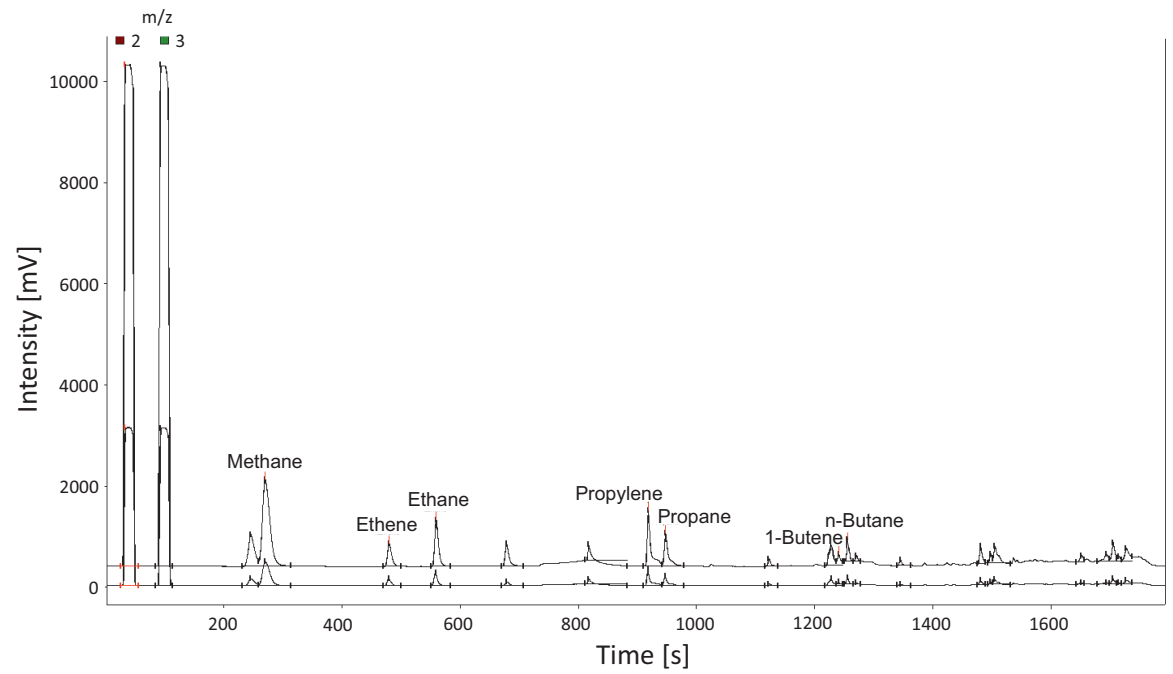

Fig. 3. Chromatogram of shale sample pyrolysed at temperature $700^{\circ} \mathrm{C}$

Rys. 3. Chromatogram próbki łupku - piroliza w temperaturze $700^{\circ} \mathrm{C}$ 


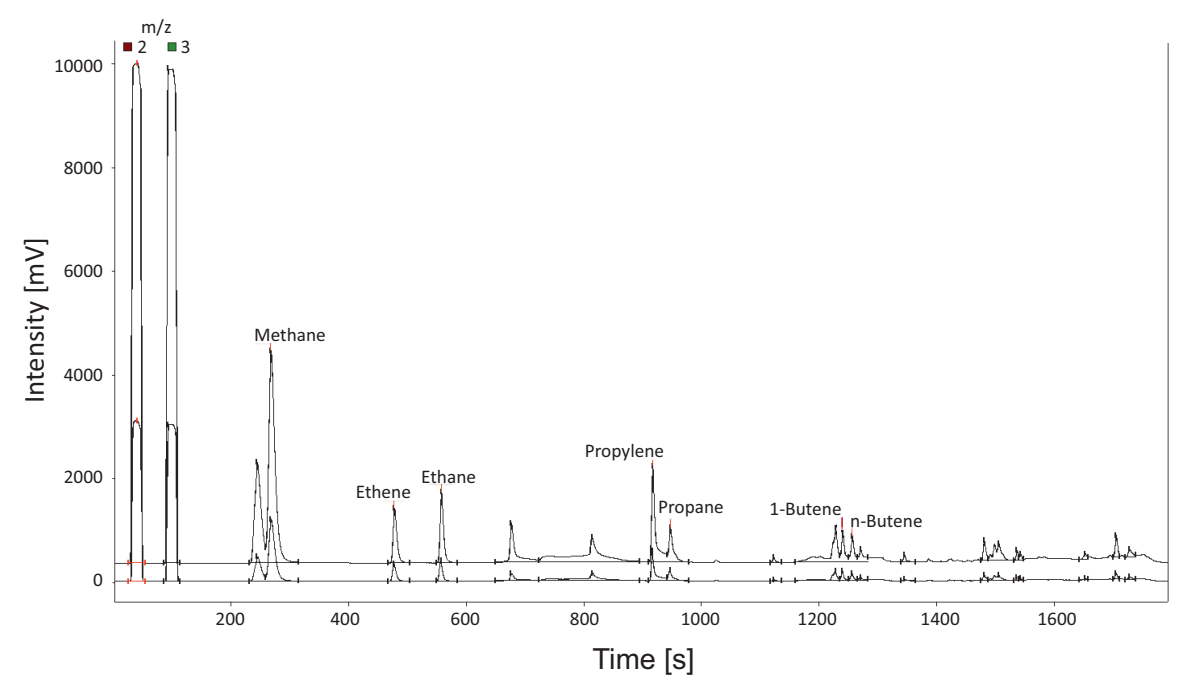

Fig. 4. Chromatogram of shale sample pyrolysed at temperature $800^{\circ} \mathrm{C}$ Rys. 4. Chromatogram próbki łupku - piroliza w temperaturze $800^{\circ} \mathrm{C}$

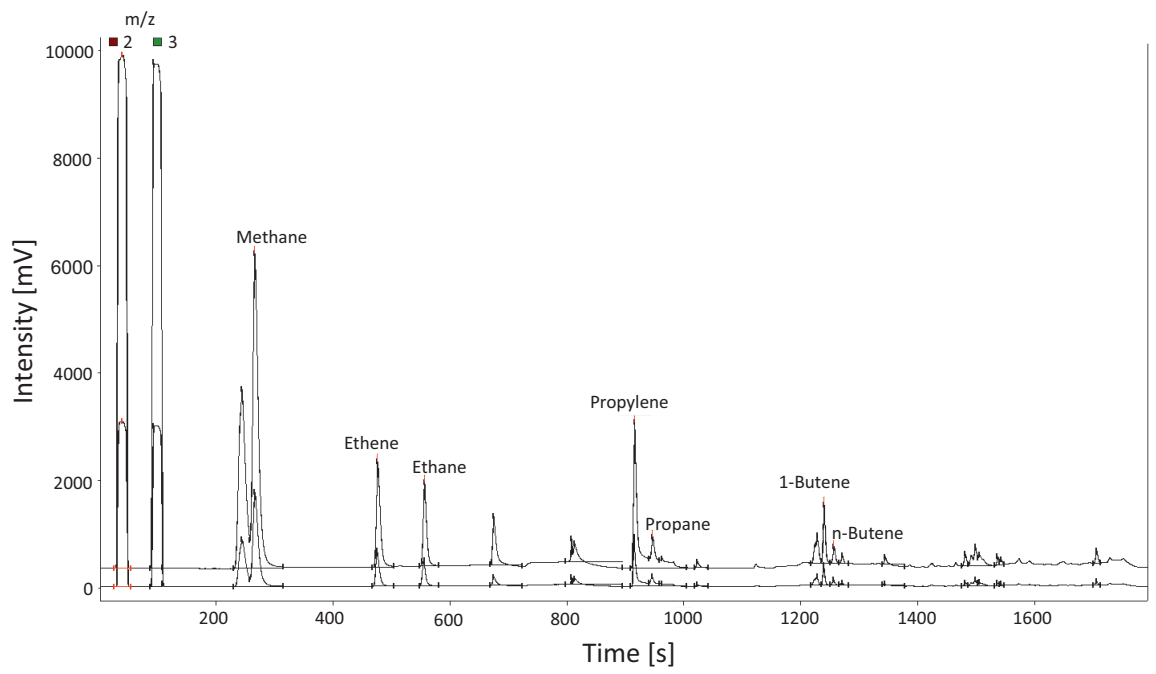

Fig. 5. Chromatogram of shale sample pyrolysed at temperature $900^{\circ} \mathrm{C}$ Rys. 5. Chromatogram próbki łupku - piroliza w temperaturze $900^{\circ} \mathrm{C}$

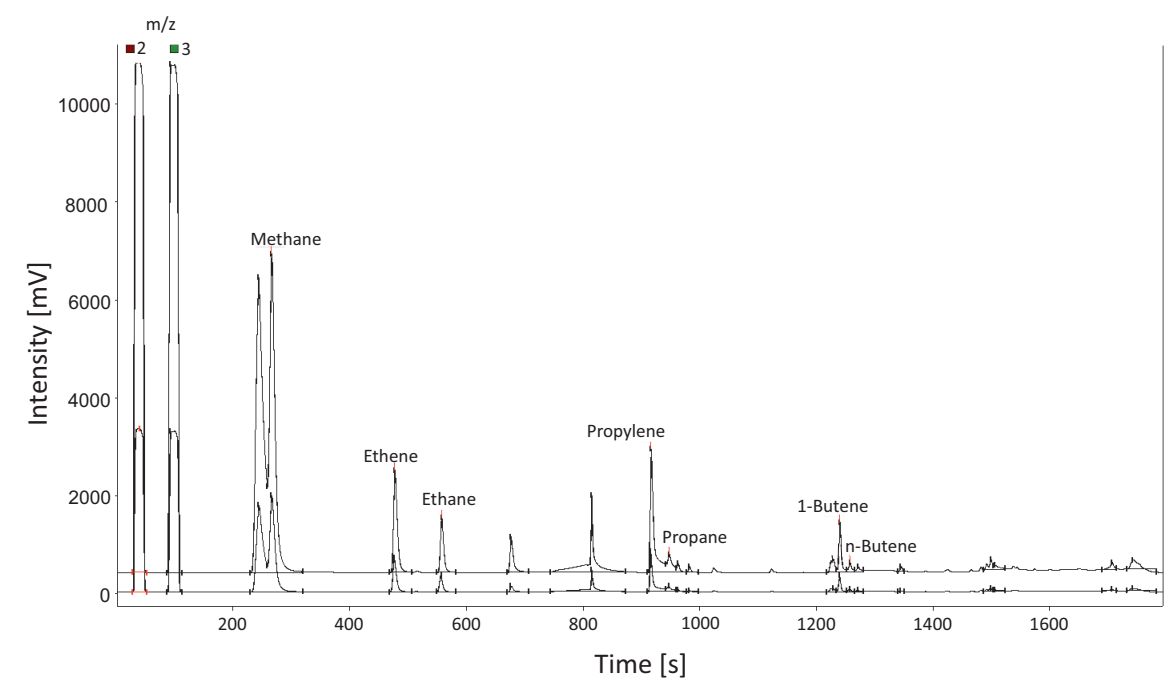

Fig. 6. Chromatogram of shale sample pyrolysed at temperature $1000^{\circ} \mathrm{C}$ Rys. 6. Chromatogram próbki łupku - piroliza w temperaturze $1000^{\circ} \mathrm{C}$ 


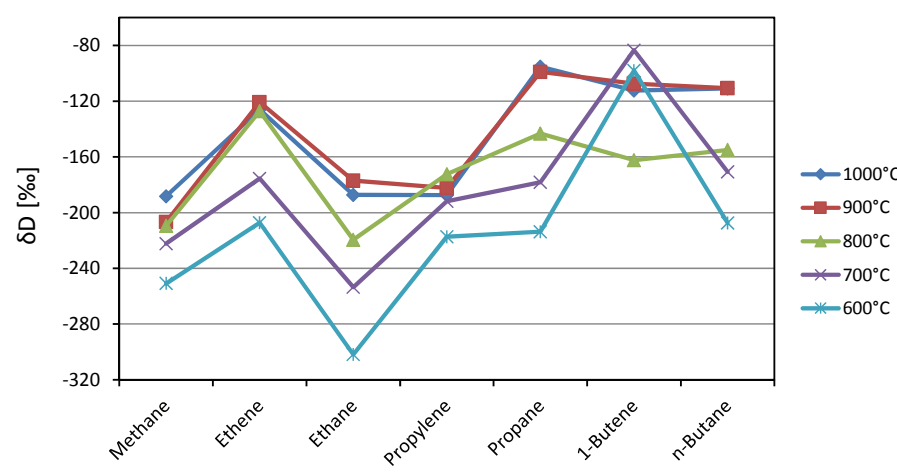

Fig. 7. Hydrogen isotopic composition of pyrolysis products obtained at different temperatures [\%o]

Rys. 7. Skład izotopowy wodoru poszczególnych produktów pirolizy w różnych temperaturach [\%]

Repeatability (minimum best expected precision) - defines the spread of measurement results of repeated tests. Conditions for the repeatability of the test method include:

- tests carried out in one laboratory (one measuring instrument);

- research conducted by one operator;

- tests carried out with the same equipment (without calibration during the test);

- research carried out over a relatively short period of time. In our study, a minimum of six replicates were performed, then the mean value, standard deviation and relative standard deviation were determined, in accordance with Magnusson et al. (2008), Michalski and Mytych (2008), Ellison and Williams (2012), Magnusson and Örnemark (2014).

\section{Repeatability}

The repeatability test was performed by analyzing the shale sample six times. The test was performed in two series: a sample weight of approximately $3 \mathrm{mg}$ and a weight of approximately $4.5 \mathrm{mg}$. The results of subsequent determinations are presented in Tables 2 and 4 . The lowest values, largest values, range, arithmetic means, standard deviations and relative standard deviations for individual compounds are presented in Tables 3 and 5. The value of relative statistical deviation (RSD) for validation should be determined individually, but the usual value of acceptance is no higher than $5 \%$. In our work, RSD does not exceed 5\% for methane, ethane and propylene (weight $3 \mathrm{mg}$ ), and for methane and ethane (weight $4.5 \mathrm{mg}$ ). The series of analyzes at the $3 \mathrm{mg}$ weight is more precise than the series at the $4.5 \mathrm{mg}$ weight. This can be connected with different peak highs (as mentioned in "Method optimization" chapter) and will be subject of further works. In addition, comparing these results with those obtained in the previous year for the carbon isotope composition, the statistical parameters take significantly worse values (in the previous year, RSD for the same components did not exceed 5\%) (Janiga and Kania, 2019).

In addition, repeatability tests were performed for EA-IRMS (elemental analyzer combined with isotope mass spectrometer) and GC-IRMS (sample injection directly into the inlet). The samples used were hard coal and natural gas (in our work, only the $\delta \mathrm{D}$ in methane was determined, the remaining hydrocarbons were found in insufficient quantities). The results of the analyzes are presented in Table 6 and the statistical parameters in Table 7. The repeatability test for GC-IRMS gave very satisfactory results: the range of hydrogen isotopic composition values is very small and the values of the standard deviation and the relative standard deviation are very low. However, such good results can be affected by homogeneity

Table 2. Hydrogen isotopic composition of pyrolysis products - $3 \mathrm{mg}$ sample weight [\%o]

Tabela 2. Skład izotopowy wodoru w produktach pirolizy - naważka około $3 \mathrm{mg}$ [\%o]

\begin{tabular}{|l|c|c|c|c|c|c|}
\cline { 2 - 7 } \multicolumn{1}{c|}{} & I & II & III & IV & V & VI \\
\hline \hline Methane & -186 & -192 & -188 & -186 & -187 & -190 \\
\hline Ethene & -117 & -144 & -126 & -119 & -121 & -131 \\
\hline Ethane & -164 & -179 & -187 & -171 & -178 & -181 \\
\hline Propylene & -175 & -192 & -187 & -179 & -182 & -188 \\
\hline Propane & -101 & -119 & -95 & -107 & -101 & -110 \\
\hline 1-Buthene & -85 & -119 & -112 & -109 & -91 & -105 \\
\hline n-Buthane & -114 & -171 & -111 & -105 & -315 & -195 \\
\hline
\end{tabular}

Table 3. Statistical parameters - $3 \mathrm{mg}$ sample weight [\%o, \%]

Tabela 3. Parametry statystyczne - naważka około 3 mg [\%, \%]

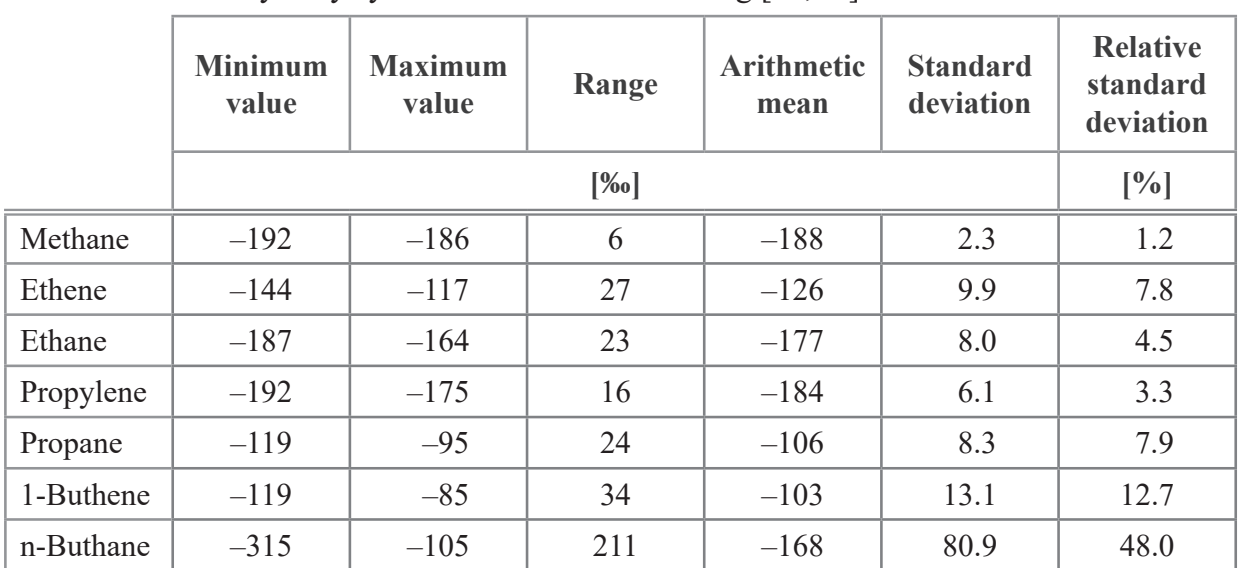


Table 4. Hydrogen isotopic composition of pyrolysis products - 4,5 mg sample weight [\%o]

Tabela 4. Skład izotopowy wodoru w produktach pirolizy - naważka około 4,5 mg [\%o]

\begin{tabular}{|l|c|c|c|c|c|c|}
\cline { 2 - 7 } \multicolumn{1}{c|}{} & I & II & III & IV & V & VI \\
\hline \hline Methane & -188 & -186 & -178 & -182 & -185 & -193 \\
\hline Ethene & -135 & -135 & -110 & -105 & -118 & -139 \\
\hline Ethane & -173 & -164 & -161 & -154 & -153 & -163 \\
\hline Propylene & -181 & -181 & -132 & -141 & -153 & -174 \\
\hline Propane & -113 & -101 & -89 & -51 & -56 & -76 \\
\hline 1-Buthene & -124 & -107 & -109 & -99 & -95 & -115 \\
\hline n-Buthane & -187 & -148 & -102 & -88 & -136 & -140 \\
\hline
\end{tabular}

Table 5. Statistical parameters - 4,5 mg sample weight

Tabela 5. Parametry statystyczne - naważka około 4,5 mg

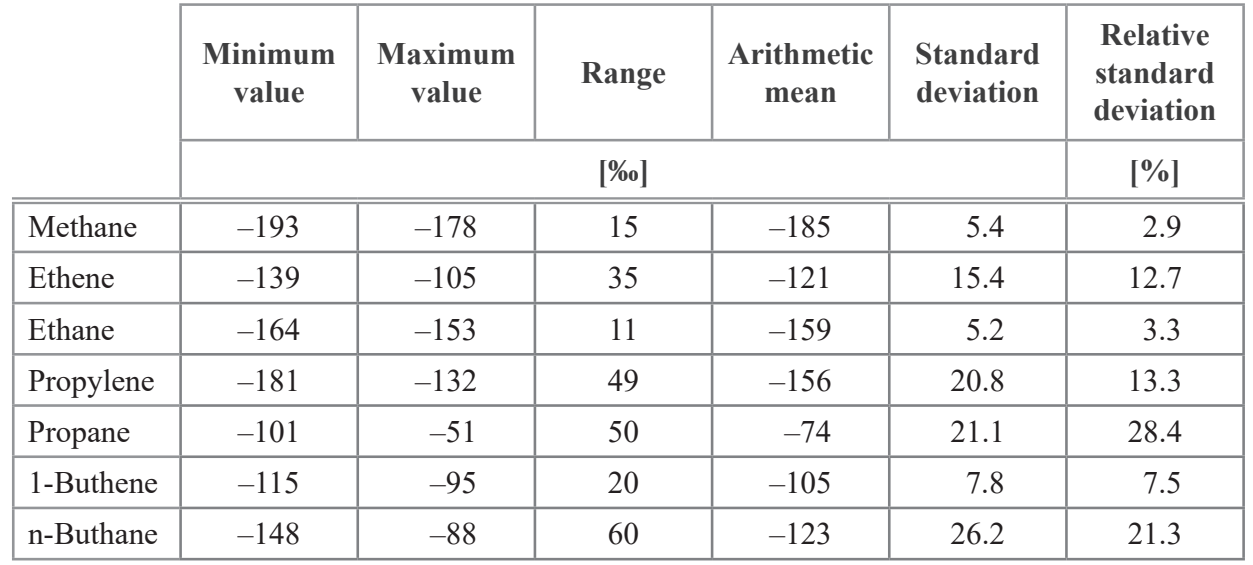

Table 6. Hydrogen isotopic composition - repeatability of EA-IRMS and GC-IRMS [\%o]

Tabela 6. Skład izotopowy wodoru - powtarzalność EA-IRMS oraz GC-IRMS [\%o]

\begin{tabular}{|l|c|c|c|c|c|c|}
\cline { 2 - 7 } \multicolumn{1}{c|}{} & I & II & III & IV & V & VI \\
\hline \hline $\begin{array}{l}\text { EA-IRMS } \\
\text { (hard coal) }\end{array}$ & -128 & -125 & -126 & -125 & -119 & -124 \\
\hline $\begin{array}{l}\text { GC-IRMS } \\
\text { (methane in } \\
\text { natural gas) }\end{array}$ & -217 & -218 & -221 & -218 & -220 & -217 \\
\hline
\end{tabular}

Table 7. Statistical parameters - repeatability of EA-IRMS and GC-IRMS

Tabela 7. Parametry statystyczne - powtarzalność EA-IRMS oraz GC-IRMS

\begin{tabular}{|c|c|c|c|c|c|c|}
\hline & $\begin{array}{l}\text { Minimum } \\
\text { value }\end{array}$ & $\begin{array}{c}\text { Maximum } \\
\text { value }\end{array}$ & Range & $\begin{array}{c}\text { Arithmetic } \\
\text { mean }\end{array}$ & $\begin{array}{l}\text { Standard } \\
\text { deviation }\end{array}$ & $\begin{array}{l}\text { Relative } \\
\text { standard } \\
\text { deviation }\end{array}$ \\
\hline & \multicolumn{5}{|c|}{ [\%o] } & {$[\%]$} \\
\hline $\begin{array}{l}\text { EA-IRMS } \\
\text { (hard coal) }\end{array}$ & -128 & -119 & 8 & -124 & 2.9 & 2.3 \\
\hline $\begin{array}{l}\text { GC-IRMS } \\
\text { (methane in } \\
\text { natural gas) }\end{array}$ & -221 & -217 & 4 & -218 & 1.7 & 0.8 \\
\hline
\end{tabular}

that the EA-IRMS system is more precise than GC-IRMS. This may be due to the type of sample (hard coal that had to be ground).

Repeatability assessed using relative standard deviation was the best (lowest value) for the GC-IRMS system $(0.8 \%)$, then that for the PyGC-IRMS system (methane at $3 \mathrm{mg}$ $-1.2 \%$ ) and for EA-IRMS (2.3\%).

\section{Conclusions}

The shale sample was pyrolyzed at $500^{\circ} \mathrm{C}, 600^{\circ} \mathrm{C}, 700^{\circ} \mathrm{C}, 800^{\circ} \mathrm{C}, 900^{\circ} \mathrm{C}$ and $1000^{\circ} \mathrm{C}$. The ratio between unsaturated and saturated hydrocarbons changes, and as the temperature increases, unsaturated ones begin to dominate. The isotopic composition of individual compounds also changes. Generally, large changes in $\delta \mathrm{D}$ can be seen with increasing temperature. The trend for all components is that at higher pyrolysis temperature, the isotopic composition is also higher (the exception is 1-butene, whose values vary widely). Of note, the differences in the isotope composition of $900^{\circ} \mathrm{C}$ and $1000^{\circ} \mathrm{C}$ are negligible.

Repeatability was assessed by analyzing the shale sample six times (on two levels: $3 \mathrm{mg}$ and $4.5 \mathrm{mg}$ ). RSD does not exceed $5 \%$ for methane, ethane and propylene (weight $3 \mathrm{mg}$ ), and for methane and ethane (weight $4.5 \mathrm{mg}$ ). The series of analyzes at the $3 \mathrm{mg}$ weight is more precise than the series at the $4.5 \mathrm{mg}$ weight. In the repeatability tests performed for EAIRMS and GC-IRMS, repeatability assessed using relative standard deviation was the best (lowest value) for the GC-IRMS system $(0.8 \%)$, then for the Py-GC-IRMS system (methane at of the sample (natural gas consisting almost exclusively of methane) and the same peak size at every analysis. Standard deviation and relative standard deviation values for the EAIRMS repeatability test were surprisingly high. It is assumed
$3 \mathrm{mg}-1.2 \%)$ and for EA-IRMS (2.3\%).

All methodology and validation details may be useful for users of similar instruments and lead to establishing Py-GCIRMS analysis procedures. 
This paper was written on the basis of the statutory work entitled: Oznaczenia składu izotopowego wodoru w układzie ,on-line” pirolizera/chromatografu i izotopowego spektrometru masowegothe work of the Oil and Gas Institute - National Research Institute was commissioned by the Ministry of Science and Higher Education; order number: 0027/SG/2019, archive number: DK-4100-0027/2019.

\section{Literature}

Carter J., Barwick V. (eds.), 2011. Good practice guide for isotope ratio Mass Spectrometry, FIRMS, ISBN: 978-0-948926-33-4.

Cengiz M. F., Durak M. Z., Ozturk M., 2014. In-house validation for the determination of honey adulteration with plant sugars (C4) by Isotope Ratio Mass Spectrometry (IR-MS). LWT-Food Science and Technology. 57: 9-15, DOI: 10.1016/j.lwt.2013.12.032.

Ellison S.L.R, Williams A. (eds.), 2012. Eurachem/CITAC guide: Quantifying Uncertainty in Analytical Measurement. Third edition. ISBN 978-0-948926-30-3. Available from www.eurachem.org.

Faghihi V., Verstappen-Dumoulin B.M.A.A., Jansen H.G., van Dijk G., Aerts-Bijma A.T., Kerstel E.R.T., Gröning M., Meijer H.A.J., 2015. A new high-quality set of singly $\left({ }^{2} \mathrm{H}\right)$ and doubly $\left({ }^{2} \mathrm{H}\right.$ and $\left.{ }^{18} \mathrm{O}\right)$ stable isotope labeled reference waters for biomedical and other isotope-labeled research. Rapid Communication Mass Spectrometry. 29(4): 311-321. DOI: 10.1002/rcm.7108.

Groot P., 2009. Handbook of stable isotope analytical techniques. Elsevier B.V. ISBN 9780080533278.

Hoefs J., 2004. Stable isotope geochemistry. Springer-Verlag. ISBN 978-3-319-78527-1.

Janiga M., Kania M., 2019. Piroliza Py-GC-IRMS - elementy walidacji oznaczania on-line składu izotopowego węgla produktów pirolizy. Nafta-Gaz, 5: 247-253, DOI: 10.18668/NG.2019.05.02.

Kania M., Janiga M., 2015. Wykorzystanie pirolitycznej chromatografii gazowej do określania składu produktów symulowanego procesu generowania węglowodorów. Nafta-Gaz, 10: 720-728. DOI: $10.18668 / \mathrm{NG} 2015.10 .02$.

Magnusson B., Naykki T., Hovind H., Krysell M., 2008. Podręcznik obliczania niepewności pomiaru w laboratoriach środowiskowych. Wydawnictwo POLLAB. ISSN 1428-6009.

Magnusson B., Örnemark U. (eds.), 2014. Eurachem Guide: The Fitness for Purpose of Analytical Methods - A Laboratory Guide to Method Validation and Related Topics. ISBN 978-91-8746159-0. Available from www.eurachem.org.

Michalski R., Mytych J., 2008. Akredytacja laboratoriów badawczych według normy PN-EN ISO/IEC 17025. Wydawnictwo Elamed. ISBN 978-83-61190-00-4.

Renterghem Van P., Polet M., Brooker L., Gansbeke Van W., Eenoo Van P., 2012. Development of a GC/C/IRMS method - Confirmation of a novel steroid profiling approach in doping control. Steroids, 77: 1050-1060. DOI: 10.1016/j. steroids.2012.05.009.

Sharp Z., 2007. Principles of stable isotope geochemistry. Pearson Prentice Hall. ISBN: 0130091391.

Vogl J., 2013. Advances in Isotope Ratio Mass Spectrometry and Required Isotope Reference Materials. Mass Spectrometry, 2(S0020): 1-7. DOI: 10.5702/massspectrometry.S0020.

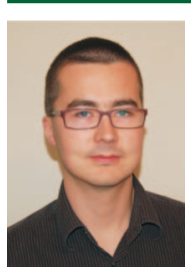

Marek JANIGA M.Sc. Eng.

Assistant

at the Department of Geology and Geochemistry Oil and Gas Institute - National Research Institute 25 A Lubicz St. 31-503 Krakow E-mail: marek.janiga@inig.pl

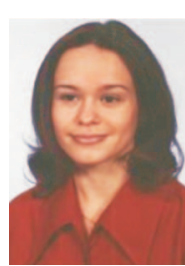

Małgorzata KANIA M.Sc.

Assistant

at the Department of Geology and Geochemistry Oil and Gas Institute - National Research Institute 25 A Lubicz St.

31-503 Krakow

E-mail:kaniam@inig.pl

\section{OFERTA BADAWCZA ZAKŁADU GEOFIZYKI WIERTNICZEJ}

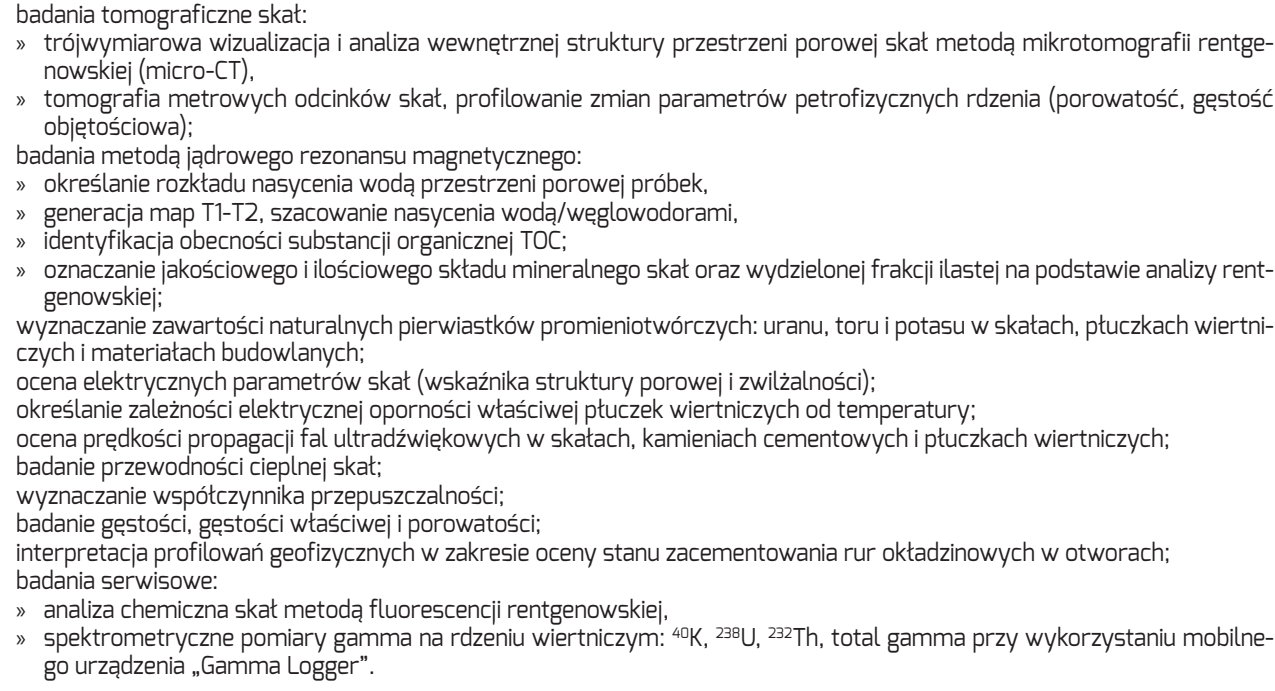

» trójwymiarowa wizualizacja i analiza wewnętrznej struktury przestrzeni porowej skat metodą mikrotomografii rentgenowskiej (micro-CT)

» tomografia metrowych odcinków skat, profilowanie zmian parametrów petrofizycznych rdzenia (porowatość, gęstość objętościowa);

badania metodą jądrowego rezonansu magnetycznego:

" określanie rozkładu nasycenia wodą przestrzeni porowej próbek,

" generacja map T1-T2, szacowanie nasycenia wodą/węglowodorami,

» identyfikacja obecności substancii organicznej TOC;

» oznaczanie jakościowego i ilościowego składu mineralnego skał oraz wydzielonej frakcji ilastej na podstawie analizy rentgenowskiej;

wyznaczanie zawartości naturalnych pierwiastków promieniotwórczych: uranu, toru i potasu w skałach, ptuczkach wiertniczych i materiatach budowlanych;

ocena elektrycznych parametrów skał (wskaźnika struktury porowej i zwilżalności);

określanie zależności elektrycznej oporności właściwej płuczek wiertniczych od temperatury;

ocena prędkości propagacii fal ultradźwiękowych w skałach, kamieniach cementowych i płuczkach wiertniczych; badanie przewodności cieplnej skat;

wyznaczanie współczynnika przepuszczalności;

badanie gęstości, gęstości wtaściwej i porowatości;

interpretacja profilowań geofizycznych w zakresie oceny stanu zacementowania rur okładzinowych w otworach badania serwisowe:

» analiza chemiczna skat metoda fluorescencji rentgenowskiej,

" spektrometryczne pomiary gamma na rdzeniu wiertniczym: ${ }^{40} \mathrm{~K},{ }^{238} \mathrm{U},{ }^{232} \mathrm{Th}$, total gamma przy wykorzystaniu mobilnego urządzenia „Gamma Logger”.

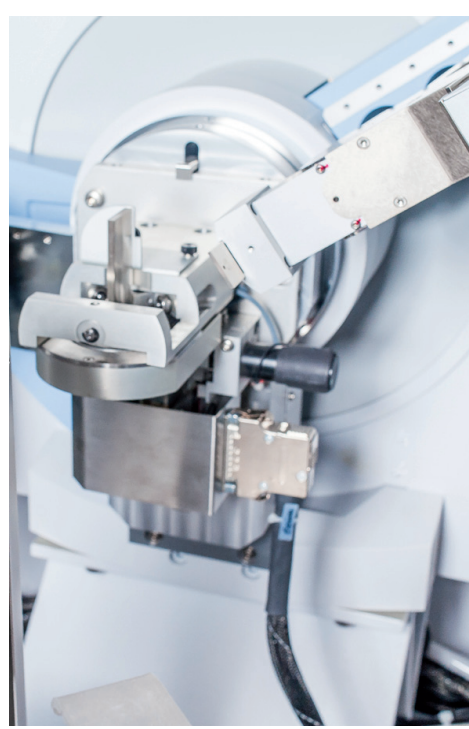

INSTYTUT NAFTY I GAZU

- Państwowy Instytut Badawczy 